\title{
Effect of Nitrogen Doping On The Structural Surface And Optical Properties Of ZnO Thin Film Prepared By Spraypyrolysis
}

Rajalekshmi ES ( $\square$ rajalekshmimsc@gmail.com )

Scott Christian College https://orcid.org/0000-0001-9686-1646

\section{Anslin Ferby}

Scott Christian College

R. Shabu

St Alphonsa College of Arts and Science

\section{A. Moses Ezhil Raj}

Scott Christian College

\section{Research Article}

Keywords: Structural Analysis, Thin films, N doped ZnO, XRD, FTIR, Optical properties, SEM.

Posted Date: September 14th, 2021

DOI: https://doi.org/10.21203/rs.3.rs-813672/v1

License: (a) (i) This work is licensed under a Creative Commons Attribution 4.0 International License. Read Full License 


\title{
EFFECT OF NITROGEN DOPING ON THE STRUCTURAL SURFACE AND OPTICAL PROPERTIES OF ZnO THIN FILM PREPARED BY SPRAYPYROLYSIS
}

\author{
E.S. Rajalekshmi ${ }^{\text {a,b }}$, V. Anslin Ferby ${ }^{\text {a,b }}$, R. Shabu ${ }^{\text {b,c }}$, A. Moses Ezhil Raj ${ }^{\text {a,b }}$ \\ ${ }^{a}$ Department of Physics \& Research Centre, Scott Christian College (Autonomous), Nagercoil, \\ 629 003, India \\ ${ }^{b}$ Affiliated to Manonmaniam Sundaranar University, Abishekapatti, Tirunelveli, 627012, India \\ ${ }^{c}$ Department of Physics, St Alphonsa College of Arts and Science, Karinkal-629 157,India
}

\begin{abstract}
:
Pure and Nitrogen doped $\mathrm{ZnO}$ thin films were fabricated using spray pyrolysis method. The influence of doping on the structural, optical and morphological properties of prepared films were studied. The prepared samples were characterized through XRD (X-Ray Diffraction), FTIR (Fourier Transform Infrared Spectroscopy), FT-RAMAN (Fourier Transform Raman), optical transmittances of prepared films were studied as a function of wavelength using UV-VIS-NIR spectrophotometer and SEM (Scanning Electron Microscope). Absorption coefficient and Extinction coefficient values were calculated. Thickness of the films were found increasing with increasing doping concentrations. Structural studies confirmed that the prepared films were highly crystalline and predominantly orientation along $\left(\begin{array}{lll}0 & 0 & 2\end{array}\right)$ direction. On varying the doping concentration of $\mathrm{N}$, a shift in the $\left(\begin{array}{lll}0 & 0 & 2\end{array}\right)$ peak was observed. FTIR and Raman spectral investigations revealed bands at specified wavenumber regions corresponding to stretching and bending vibrations of $\mathrm{Zn}$ and O. High resolution SEM images proved the presence of regular distribution of grains and the surface was found continuous, free from crack and holes. EDAX spectrum shows the attained films contain of Zinc, Oxygen and Nitrogen elements. Present investigations confirmed the fusion of nitrogen into $\mathrm{ZnO}$ lattice and modified the structural, optical and morphological properties of $\mathrm{ZnO}$ films.
\end{abstract}

Keywords: Structural Analysis; Thin films; N doped ZnO; XRD; FTIR; Optical properties; SEM.

*Corresponding author E-mail: rajalekshmimsc@gmail.com 


\section{Introduction:}

$\mathrm{ZnO}$ is a direct, wide bandgap semiconducting material with many properties for optoelectronics, transparent electronics and sensor applications. It has been used in wide range of applications such as, piezoelectric transducers, varistors and transparent conducting electrodes. $\mathrm{ZnO}$ has several attractive characteristics for electronic and optoelectronic devices. It has direct bandgap energy of $3.37 \mathrm{eV}$ and a large exciton binding energy of $60 \mathrm{meV}$ at room temperature. Several methods has been used to prepare undoped and $\mathrm{N}$ doped $\mathrm{ZnO}$ thin films such as, chemical vapor deposition [1,2], electrochemical deposition [3,4], sol-gel process [5,6], pulsed filtered cathodic vacuum arc deposition (PFCVAD) [7], Magnetron Sputtering [8-10], MOCVD [11-15] pulsed laser deposition [16, 17], ion beam sputter deposition [18], Electrospraying technique [19], Spin Coating [20], spray pyrolysis [21-23] etc. Among them, spray pyrolysis technique is the best method to prepare thin films for its simplicity, low cost and process yield $[3,16,17]$. Also the properties of films can be easily modified by adjusting the spray parameters [15]. In the present study, spray pyrolysis method is engaged to deposit pure and nitrogen doped $\mathrm{ZnO}$ thin films for different doping concentrations. The influence of nitrogen doping on structural, optical and morphological properties of prepared thin films are analyzed using series of characterizations and the obtained results are thoroughly discussed.

\section{Experimental Details:}

Undoped and $\mathrm{N}$ doped $\mathrm{ZnO}$ thin films grown on glass substrate. Zinc acetate dehydrate [ $\left.\mathrm{Zn}\left(\mathrm{CH}_{3} \mathrm{COO}\right)_{2} . \mathrm{H}_{2} \mathrm{O}\right](0.2 \mathrm{M})$ was used as an initial precursor dissolved in deionized water, ethanol and ammonium nitrate $\left(\mathrm{NH}_{4} \mathrm{NO}_{3}\right)$ was added as a dopant concentration. Different solution concentrations $(0.1,0.2,0.3$, and $0.4 \mathrm{ml}$.) were prepared for the same $\mathrm{Zn:} \mathrm{N}$ (1: 3) ratio. Few drops of $\mathrm{HCl}$ was added to the obtained mixture to avoid the formation of hydroxides. 
Prepared precursor was sprayed on glass substrates preheated at a constant temperature of $350{ }^{\circ} \mathrm{C}$. The structural properties were studied by X-Ray diffraction (PANANALYTICAL XPERT-PRO). Phase identification was confirmed by FTIR (Thermo Nicolet Avtar) and FT-Raman. The optical properties of the prepared $\mathrm{ZnO}$ thin films were studied by UV-VIS Spectrometer. The surface morphology of the prepared films were recorded using SEM (SEM JEOL JSM-6390LV) and Atomic Force Microscope respectively. Elemental composition of the prepared films were studied by energy dispersive X-Ray (EDX) instrument.

\section{Results and Discussion:}

\subsection{Structural Studies}

Fig .1(a) shows the XRD pattern of pure and $\mathrm{N}$ doped $\mathrm{ZnO}$ thin films deposited at different solution concentrations $(\mathrm{x}=0 \mathrm{ml}, 0.1 \mathrm{ml}, 0.2 \mathrm{ml}, 0.3 \mathrm{ml}$ and $0.4 \mathrm{ml})$.
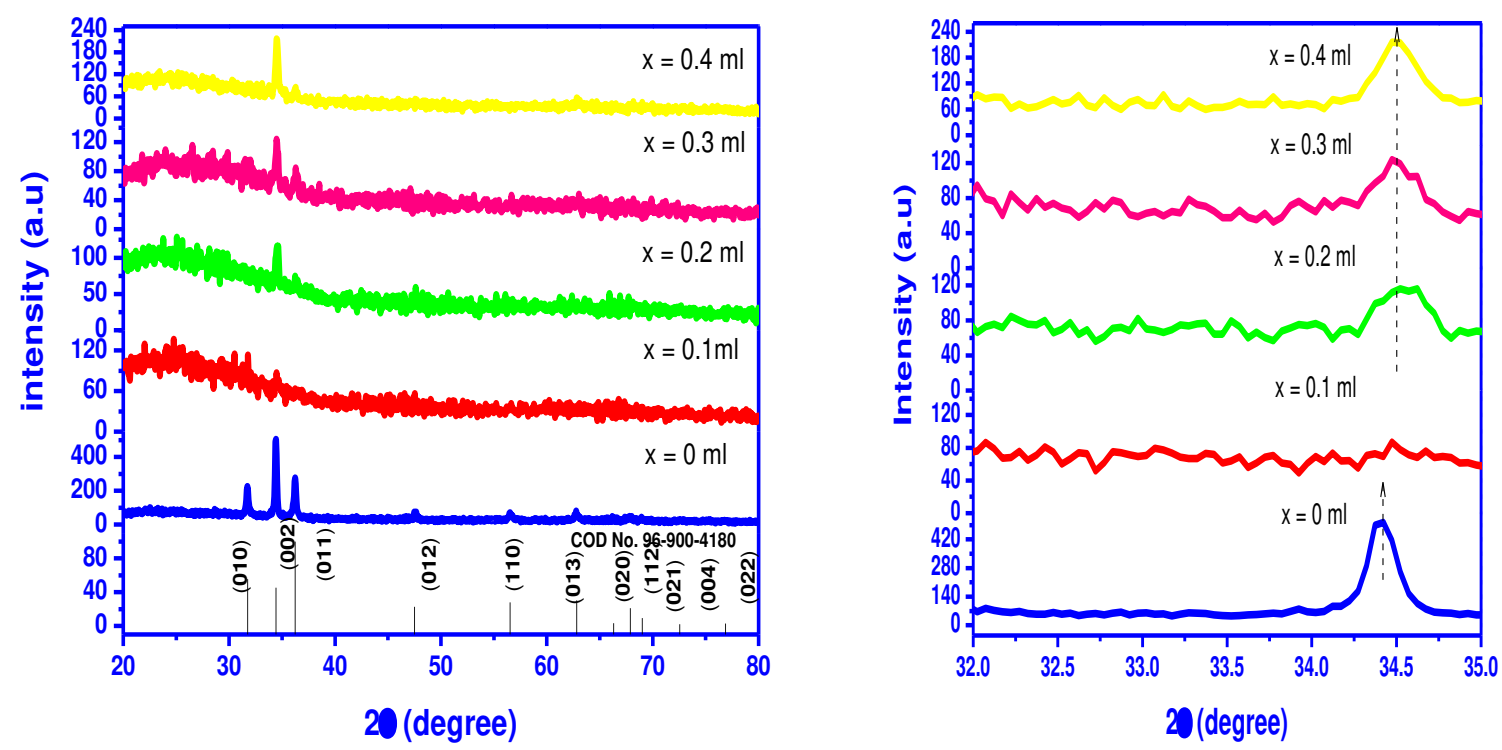

Fig. 1 (a) XRD patterns of pure and N-doped $\mathrm{ZnO}$ films for different concentrations ( $x$ ) (b) Shifts in (lll 0 2) peak position and peak widening in pure and $\mathrm{N}$ doped $\mathrm{ZnO}$ thin films. 
The diffracted peaks in the pattern can be indexed for its hexagonal wurtzite structure by COD card No: 96-900-4180. No diffraction peaks are identified at lower doping concentration of nitrogen. When the doping concentration is increased, intensity of (002) peak begins to arise and its intensity increases with doping. ZnO:N films exhibit high crystallinity and are preferentially orientation along the (002) direction. No other impurity peaks due to nitrogen was detected in the XRD. This shows the purity of the prepared films and $\mathrm{N}$ is well incorporated at the $\mathrm{O}$ lattice site in the hexagonal wurtzite structure of $\mathrm{ZnO}$. Fig. 1b, shows the shift in $\left(\begin{array}{lll}0 & 0 & 2\end{array}\right)$ peak position and its widening with doping. The shift in the $\left(\begin{array}{lll}0 & 0 & 2\end{array}\right)$ peak is prominent with varying doping concentration, which may be due to the stress in the films i.e, tensile or compressive strain, the peak position shifts respectively towards higher or lower angle [18]. Shift is clearly realized in highly doped film and this is the sign of $\mathrm{N}$ doping into $\mathrm{ZnO}$ lattice [19].

Lattice parameters $a$ and $c$ were calculated using the relation:

$$
\frac{1}{d^{2}}=\frac{4}{3}\left[\frac{h^{2}+h k+k^{2}}{a^{2}}\right]+\frac{l^{2}}{c^{2}}
$$

Crystallite size of prepared pure and $\mathrm{N}$ doped $\mathrm{ZnO}$ thin films were calculated using Scherrer's formula [20].

$$
\mathrm{D}=\frac{0.9 \lambda}{\beta \cos \theta}
$$

where, $\lambda$, is the wave length of $\mathrm{CuK}_{\alpha}$ radiation (1.5406 $\AA$ ), $\theta$, is the Bragg's diffraction angle, $\beta$, is the FWHM.

Dislocation density $(\delta)$ was calculated using the formula:

$$
\delta=\frac{1}{D^{2}}\left(\frac{\text { lines }}{m^{2}}\right)
$$

where, $\mathrm{D}$, is the grain size.

Microstrain $(\varepsilon)$ of $\mathrm{ZnO}$ films are calculated using the relation:

$$
\varepsilon=\frac{\beta \cos \theta}{4}
$$


where, $\beta$, the FWHM in radians, $\theta$, is the diffracting angle.

The variation of thickness, crystallite size, dislocation density, and microstrain with doping concentration are given in Table 1 .

Table 1 Calculated structural parameters of pure and N-doped $\mathrm{ZnO}$ thin films

\begin{tabular}{|c|c|c|c|c|c|c|c|c|c|}
\hline \multirow{2}{*}{$\begin{array}{c}\text { Sample } \\
\text { Details }\end{array}$} & $\begin{array}{c}\text { Lattice Parameter } \\
(\AA)\end{array}$ & $\begin{array}{c}\text { Unit Cell } \\
\text { Volume } \\
(\AA)\end{array}$ & $\begin{array}{c}\text { Crystallite } \\
\text { Size }(\mathrm{nm}) \\
\left(\mathrm{x} 10^{-9}\right)\end{array}$ & $\begin{array}{c}\text { Microstrain } \\
\left(\varepsilon \times 10^{-3}\right)\end{array}$ & $\begin{array}{c}\text { Dislocation } \\
\text { Density } \\
\left(\mathrm{x} 10^{14}\right) \\
\text { Lines/meter }\end{array}$ & $\begin{array}{c}\text { Thickness } \\
(\mu \mathrm{m})\end{array}$ & $\begin{array}{c}\text { No of } \\
\text { Crystallites } \\
\left(\mathrm{x} 10^{14}\right)\end{array}$ & $\begin{array}{c}\text { Density } \\
\left(\mathrm{g} / \mathrm{cm}^{3}\right)\end{array}$ \\
\hline $\begin{array}{c}\text { Standard } \\
\text { Value }\end{array}$ & 3.2530 & 5.2070 & 47.72 & & & & & & 5.66 \\
$\mathrm{x}=0$ & 3.2556 & 5.2092 & 47.81 & 40.274 & 8.2026 & 6.1652 & 1.21 & 7.45 & 5.6525 \\
$\mathrm{x}=0.1$ & - & - & - & - & - & - & 1.71 & - & - \\
$\mathrm{x}=0.2$ & 5.2531 & 5.1791 & 47.71 & 24.14 & 1.4996 & 1.499 & 1.77 & 0.30 & 5.6737 \\
$\mathrm{x}=0.3$ & 3.2531 & 5.1960 & 47.72 & 35.32 & 8.2022 & 1.0250 & 1.87 & 1.49 & 5.6925 \\
$\mathrm{x}=0.4$ & 3.2524 & 5.2084 & 47.81 & 35.31 & 6.1520 & 4.10 & 2.14 & 1.71 & 5.6752 \\
\hline
\end{tabular}

As observed, the lattice parameter decreases with doping concentration. Also the crystallite size decreases from 40.274 to $24.14 \mathrm{~nm}$ then increases to $35.32 \mathrm{~nm}$ with doping. The increase in the crystallite size reveals the enhancement of crystallinity under $\mathrm{c}$ axis orientation of $\mathrm{ZnO}$ thin films. Ebru Senadim Tuzemen reported grain size first increases then decreases [8]. Dislocation density values increases with increasing doping concentration. Since dislocation density and microstrain values are inversely proportional, initially microstrain values decreases and then increases. Calculated lattice constant values of $\mathrm{N}$ zoped $\mathrm{ZnO}$ samples are smaller than undoped $\mathrm{ZnO}$ samples.

\subsection{Phase Identification}

\subsubsection{FTIR Analysis of ZnO Thin Films}

Vibrational studies can be used to investigate the chemical bonding, defect structures, impurity content etc. The presence of various vibrational modes in pure and $\mathrm{N}$ doped $\mathrm{ZnO}$ thin 
films were analyzed using FTIR in the wave number range from $400-4000 \mathrm{~cm}^{-1}$, which is shown in Fig. 2.

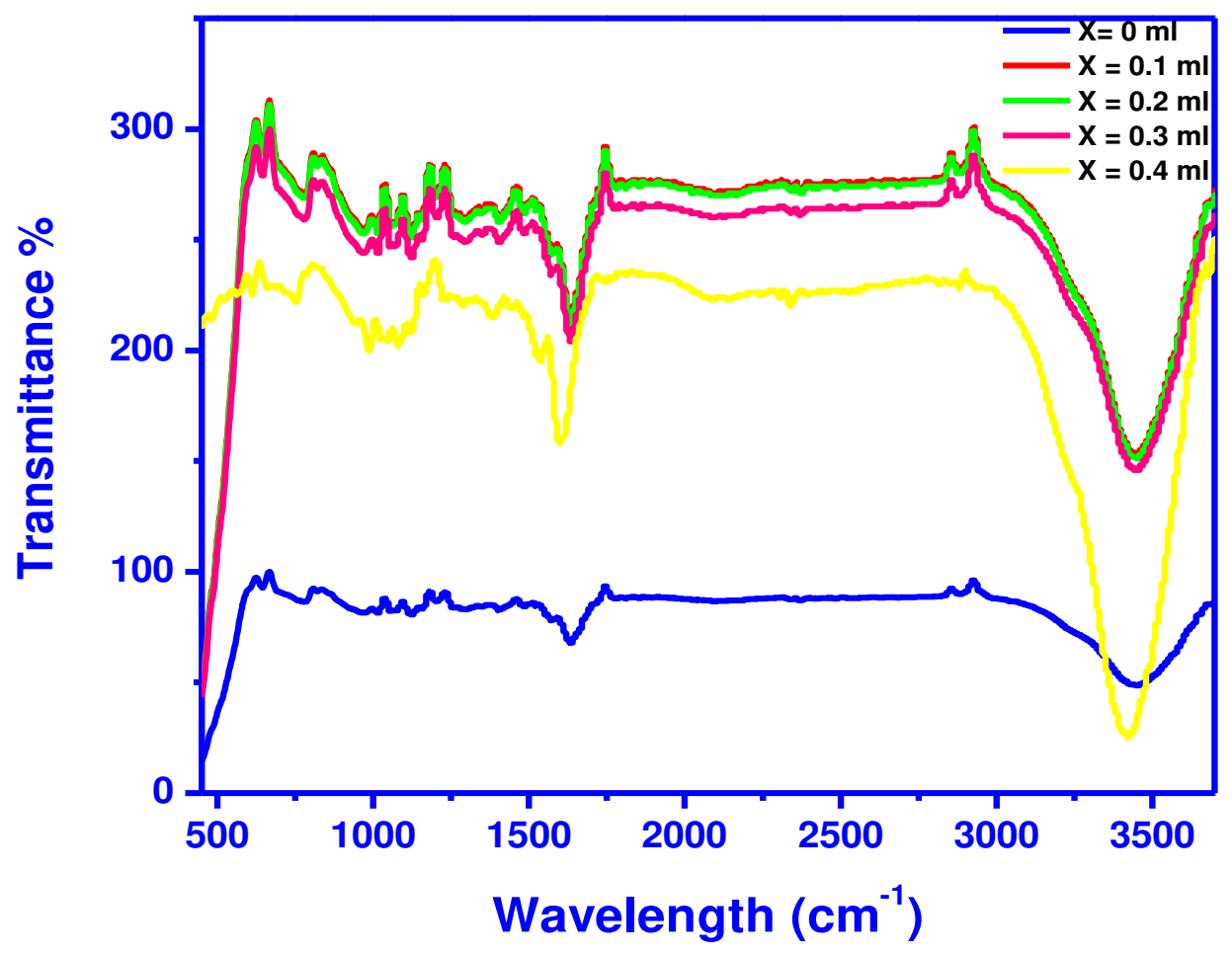

Fig. 2 FTIR spectra of pure and $\mathrm{N}$ doped $\mathrm{ZnO}$ thin films for different concentrations (x)

The characteristic IR peaks below $1000 \mathrm{~cm}^{-1}$ is very important to study the presence or absence of $\mathrm{Zn}-\mathrm{O}$ bonds and the functional groups. The IR bands at 407, 512 and $623 \mathrm{~cm}^{-1}$ corresponds to vibrational modes of $\mathrm{Zn}-\mathrm{O}$ bond in the prepared $\mathrm{ZnO}$ thin films. The vibrational mode at $886 \mathrm{~cm}^{-1}$ is related to oxygen site bound to the lattice $\mathrm{Zn}$ site [28]. Another sharp peak at $1640 \mathrm{~cm}^{-1}$ is attributed to $\mathrm{H}-\mathrm{O}-\mathrm{H}$ bending vibration which may due to presence water species in prepared thin films. This band is more prominent in doped samples, which signify the incorporation of nitrogen ions into $\mathrm{ZnO}$ lattice. Also FTIR spectrum reveals the presence of stretching vibrational bond of $\mathrm{O}-\mathrm{H}$ around $3450 \mathrm{~cm}^{-1}$ for undoped and $\mathrm{N}$ doped samples. The 
gradual shifts in the absorption frequency with $\mathrm{N}$-doping are caused by the difference in the bond lengths that occurs when $\mathrm{N}$ ions replace native ions [30]. For undoped and $\mathrm{N}$ doped $\mathrm{ZnO}$ thin films modes observed from 1000 to $1500 \mathrm{~cm}^{-1}$ and these modes are usually assigned to $\mathrm{O}-\mathrm{C}=\mathrm{O}$ (symmetric and asymmetric stretching) vibrations and $\mathrm{C}-\mathrm{O}$ vibrations due to ambient atmosphere. [31].

\subsubsection{FT- Raman Analysis}

Fig. 3 shows the FT-Raman spectrum of pure and N-ZnO thin films. Raman shift can be observed in the wave number region $400-4000 \mathrm{~cm}^{-1}$.

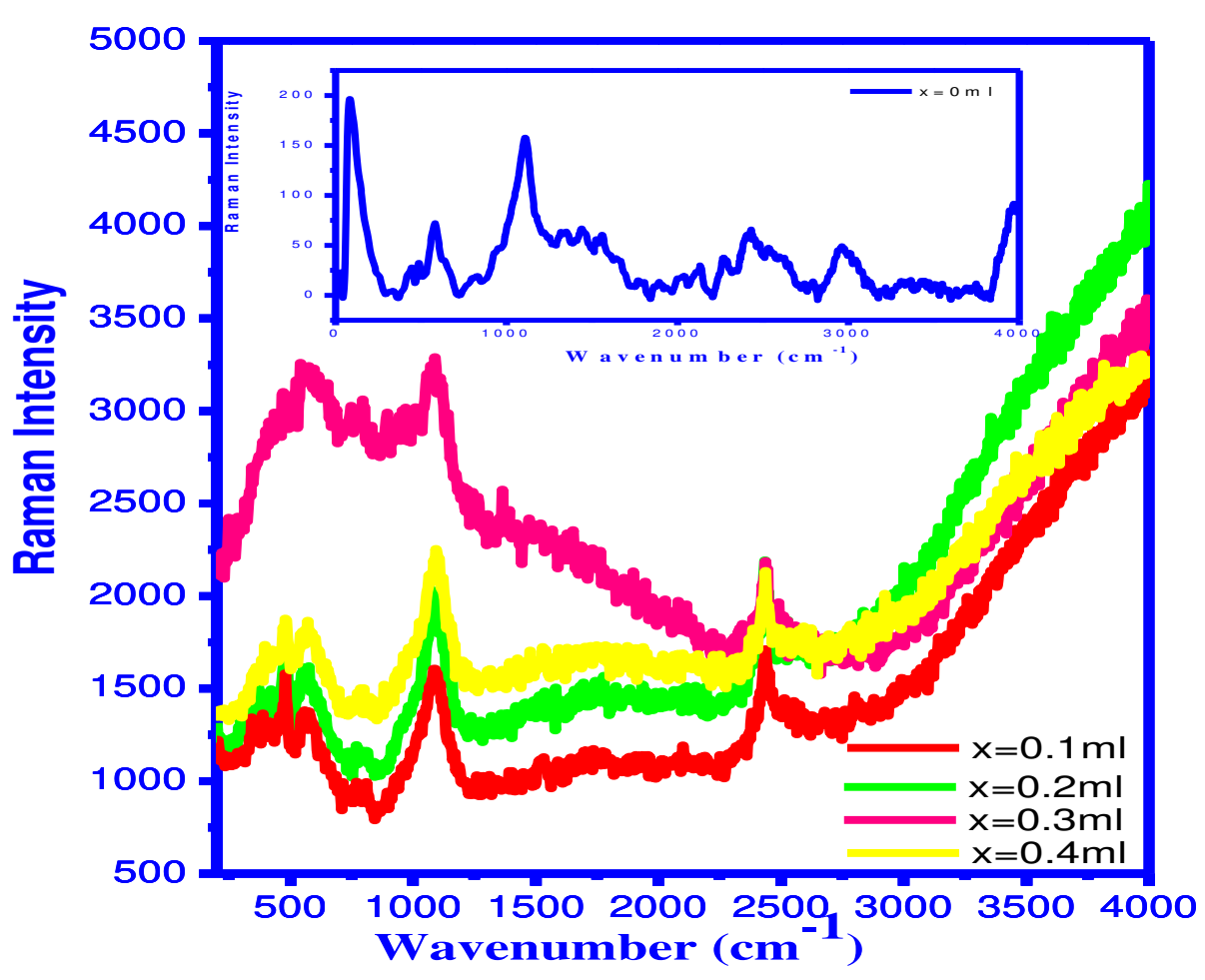

Fig. 3 FT-RAMAN spectra of pure and $\mathrm{N}$ doped $\mathrm{ZnO}$ thin films for different concentrations $(\mathbf{x})$ 
The wurtzite structure of $\mathrm{ZnO}$ belongs to space group $\mathrm{C}_{6 \mathrm{v}}\left(\mathrm{P}_{3} \mathrm{mc}\right)$ [32]. So one primitive cell includes two formula units, with all atoms occupying $2 \mathrm{~b}$ sites of symmetry $\mathrm{C}_{3 \mathrm{v}}$. Hence group theory predicts the existence of optic modes: $\Gamma=\mathrm{A}_{1}+2 \mathrm{~B}_{1}+\mathrm{E}_{1}+2 \mathrm{E}_{2}$ at the th Brillouin zone. Out of the modes, $\mathrm{B}_{1}$ (low) and $\mathrm{B}_{1}$ (high) are silent modes; $\mathrm{A}_{1}, \mathrm{E}_{1}$ and $\mathrm{E}_{2}$ modes are Ramanactive; $A_{1}$ and $E_{1}$ are infrared-active. Therefore, $A 1$ and $E 1$ split into longitudinal optical (LO) and transverse optical (TO) components. The Raman spectra of $\mathrm{N}$ doped ZnO films exhibits bands centered near 331, 481, 531, 576, and $1096 \mathrm{~cm}^{-1}$. Among these bands, vibrational mode $2 \mathrm{E}_{2}(\mathrm{M})$ at $331 \mathrm{~cm}^{-1}$ and $\mathrm{E}_{2}$ (high) at $481 \mathrm{~cm}^{-1}$ corresponds to $\mathrm{ZnO}$. The transition $2 \mathrm{E}_{2}(\mathrm{M})$ at $331 \mathrm{~cm}^{-1}$ is due to possible multiple phonon-scattering processes and may be associated with Zn-O vibration. Peak E2 (high) at $481 \mathrm{~cm}^{-1}$ corresponds to oxygen atom. The mode around $576 \mathrm{~cm}^{-1}$ is also ascribed as nitrogen related local vibrational mode (LVM) in the back scattering geometry with crossed polarization. The peaks at $1096 \mathrm{~cm}^{-1}$ are probably associated with $\mathrm{C}-\mathrm{O}$ bonds [23]. The shoulder of this peak can be possibly from the O-O stretching vibrations of two different dioxygen species bonded to surface defect site. With the increase in precursor concentration the peak intensities increases due to the improvement in the crystallinity of thin films.

\subsection{Optical Studies:}

Optical absorption spectra of pure and $\mathrm{N}$ doped $\mathrm{ZnO}$ thin films in the wavelength range 200-800 nm are shown in Fig.4. Optical peroperties will change consistent with energy gap changes, when the nitrogen doped with $\mathrm{ZnO}$ thin film. From the absorbance and transmission spectra band gap energy calculated. 


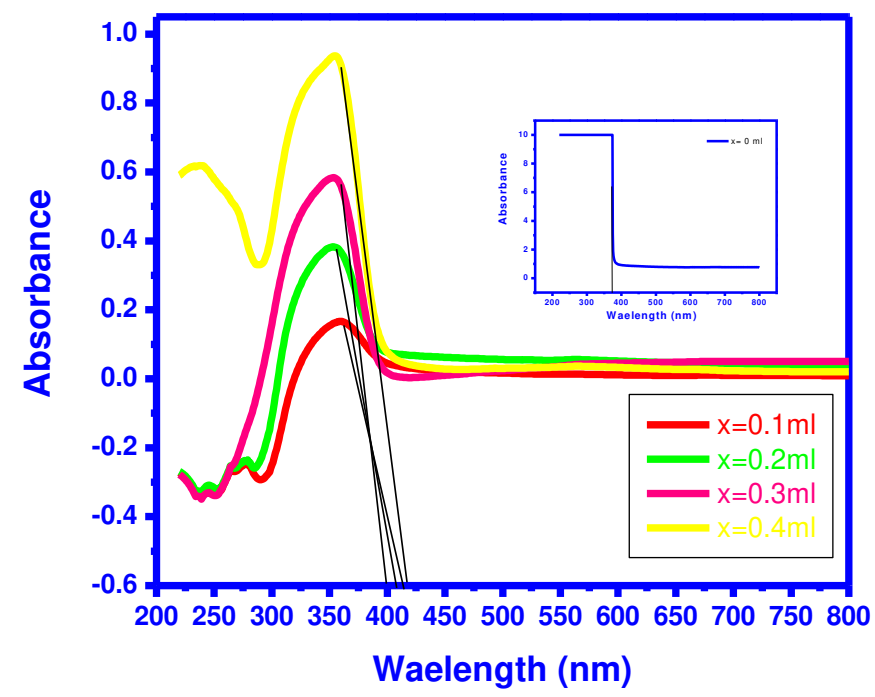

Fig. 4 Optical absorption spectra of pure and $\mathrm{N}$ doped $\mathrm{ZnO}$ thin films for different concentrations ( $\mathbf{x})$.

Fig.4 show the UV-vis patterns of all the films near absorption edges, which are indicated with dashed lines. A great difference of the $\mathrm{ZnO}: \mathrm{N}$ thin films from the undoped $\mathrm{ZnO}$ is the redshift. As we can see in fig.4, the absorption edge gradually shifts to long wavelength direction as nitrogen solution concentration increases. May be this red-shift result suggests a uniform substitution of $\mathrm{N}$ for $\mathrm{O}$ in the lattice [15].

Fig. 5 Shows the transmittance spectra of pure and $\mathrm{N}$ doped $\mathrm{ZnO}$ thin films for different concentrations. 


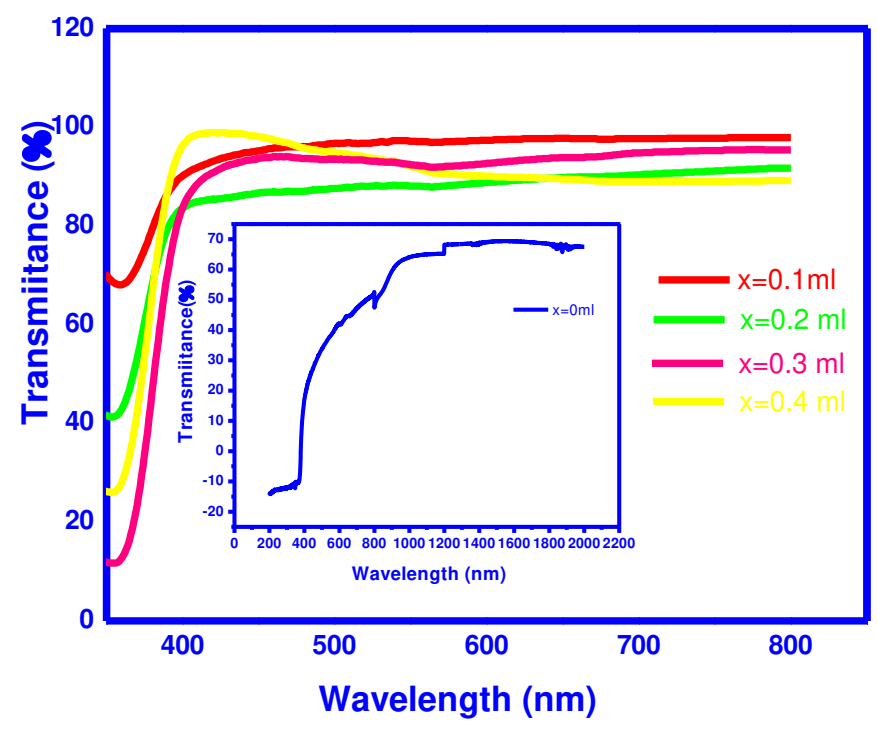

Fig. 5 Optical transmittance (T) spectra of pure and $\mathrm{N}$ doped $\mathrm{ZnO}$ thin films for different concentrations $(\mathbf{x})$

Table.2 Trnamittance percentage of pure and $\mathrm{N}$ doped $\mathrm{ZnO}$ thin films for different concentrations $(\mathbf{x})$

\begin{tabular}{|c|c|c|}
\hline $\begin{array}{c}\text { Precursor } \\
\text { Concentration }(\mathbf{M})\end{array}$ & Thickness & $\begin{array}{c}\text { Transmittance } \\
(\boldsymbol{\mu} \mathbf{m})\end{array}$ \\
\hline $\mathrm{x}=0$ & 1.21 & 67 \\
\hline $\mathrm{x}=0.1$ & 1.71 & 97 \\
\hline $\mathrm{x}=0.2$ & 1.77 & 95 \\
\hline $\mathrm{x}=0.3$ & 1.87 & 91 \\
\hline $\mathrm{x}=0.4$ & 2.14 & 88 \\
\hline
\end{tabular}

The transmittance percentage was calculated for wavelengths in the range from $400 \mathrm{~nm}$ to $800 \mathrm{~nm}$.Transmittance percentage is high $(>88 \%)$ in $\mathrm{N}$ doped $\mathrm{ZnO}$ thin films while lower percentage $(67 \%)$ obtained in Pure $\mathrm{ZnO}$ thin films. The spectra reveal that the films have a 
sharp absorption edge in the region of about $380 \mathrm{~nm}$, which is characteristic of $\mathrm{ZnO}$ and indicated that the films were of good optical quality. Obtained $\mathrm{ZnO}$ samples are suitable for opto electronics devices because of its higher tranmittance percentage for the wavelength greater than $380 \mathrm{~nm}$ region.

The optical absorption coefficient can be calculated using the Lambert law relation,

$$
\alpha(\lambda)=1 / t \ln (1 / T(\lambda))
$$

where, ' $\mathrm{t}$ ' is the film thickness, ' $\mathrm{T}$ ' is the transmission co-efficient respectively. The extinction coefficient can be related the absorption co-efficient by the following equation;

$$
\mathrm{K}(\lambda)=\frac{\alpha(\lambda) \lambda}{4 \pi}
$$

where, $k(\lambda)$ is extinction coefficient. Fig. (6a) and (6b) shows the absorption coefficient and extinction coefficients of $\mathrm{ZnO}$ film obtained at various wavelength of $\mathrm{ZnO}$.
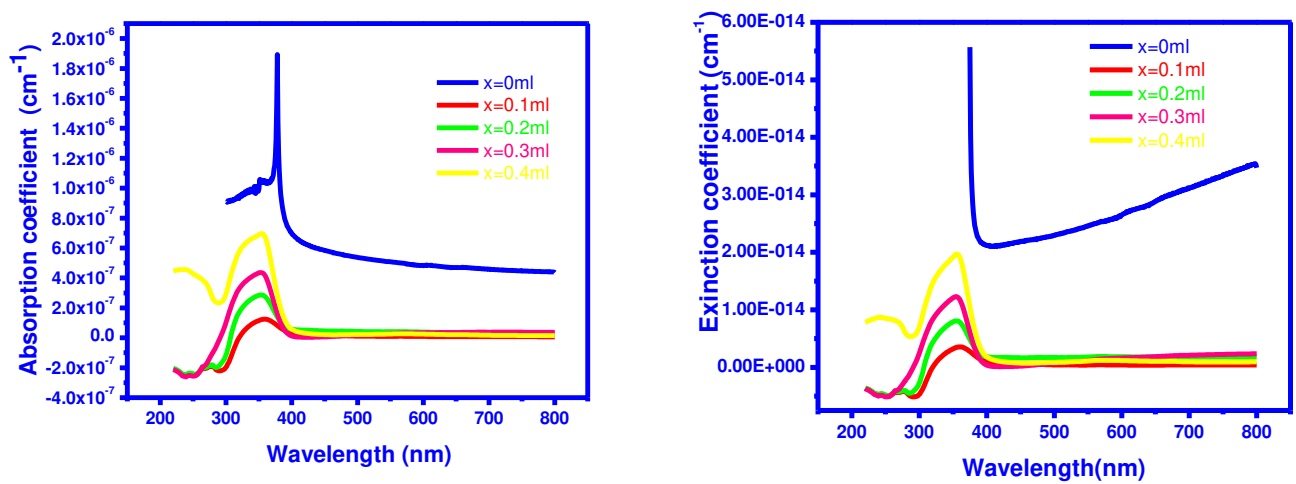

Fig. (6a) \& (6b) Variation of optical absorption coefficient and extinction coefficients of pure and $\mathbf{N}$ doped $\mathrm{ZnO}$ thin films for different concentrations $(\mathbf{x})$

The variation of absorption coefficient $(\alpha)$ with wavelength is reported for doped and undoped $\mathrm{ZnO}$ thin films. Higher $\alpha$ values are obtained for undoped $\mathrm{ZnO}$ thin films. Fig. 6b 
shows the extinction coefficient variations with increasing wavelength. The extinction coefficient is high in undoped samples when compared to $\mathrm{N}$ doped $\mathrm{ZnO}$ thin films. Initially $\mathrm{K}$ values increases in UV region due to the intrinsic absorption in the upper gap energies then decreases in the visible region which confirms the layers are transparent [33].

The band gap energy of thin films can be calculated using Tauc plots, drawn between photon energy $(\mathrm{h} \gamma)$ and square of the absorption coefficient $(\alpha \mathrm{h} \gamma)^{2}$. This plot yields a straight line in the high energy region of the spectrum. The intercept of the plot in energy axis gives the optical band gap energy 'Eg' in electron volt. Fig. 6 shows the Tauc plots drawn for ZnO films deposited at various precursor concentrations.

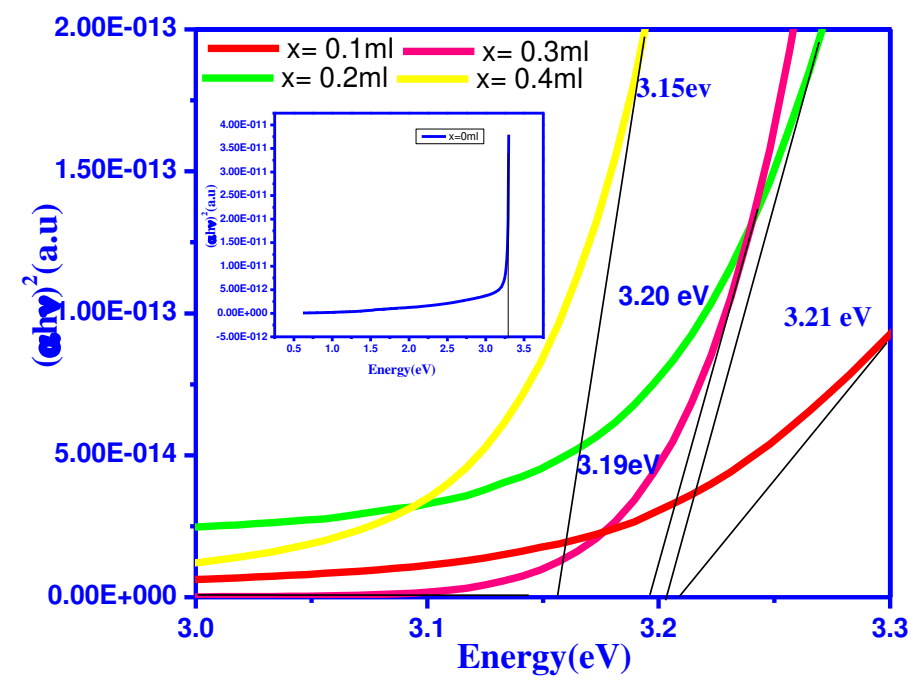

Fig. 7 Tauc Plot of pure and $\mathrm{N}$ doped $\mathrm{ZnO}$ thin films for different concentrations (x) 
Table 3 Optical band gap energy of $\mathrm{ZnO}$ films

\begin{tabular}{|c|c|c|}
\hline $\begin{array}{c}\text { Precursor } \\
\text { Concentration }\end{array}$ & $\begin{array}{c}\text { Thickness } \\
(\mu \mathrm{m})\end{array}$ & $\begin{array}{c}\text { Band gap energy } \\
(\mathrm{eV})\end{array}$ \\
\hline $\mathrm{x}=0$ & 1.21 & 3.29 \\
\hline $\mathrm{x}=0.1$ & 1.71 & 3.21 \\
\hline $\mathrm{x}=0.2$ & 1.77 & 3.20 \\
\hline $\mathrm{x}=0.3$ & 1.87 & 3.19 \\
\hline $\mathrm{x}=0.4$ & 2.14 & 3.15 \\
\hline
\end{tabular}

From the Tauc plot, the optical band gap energy can be determined by extrapolating liner portion of the curve existing in the high energy side to the $\mathrm{x}$-axis. The intercept of the line on the energy scale give the optical band gap energy. Bandgap values are high $(3.29 \mathrm{eV})$ undoped $\mathrm{ZnO}$ thin films. Band gap values decreases from 3.21 to $3.15 \mathrm{eV}$, when nitrogen was added to $\mathrm{ZnO}$. It is due to the existence of $\mathrm{Zn}-\mathrm{N}$ bond having smaller ionicity and formation of $\mathrm{Zn}-\mathrm{O}$ bonds [7]. Obtained results are in good agreement with the previous reported results.

\subsection{Surface Analysis}

\subsubsection{Scanning Electron Microscope}

Fig. 8 shows the SEM micrographs of pure and $\mathrm{N}$ doped $\mathrm{ZnO}$ thin films for different doping concentrations. 

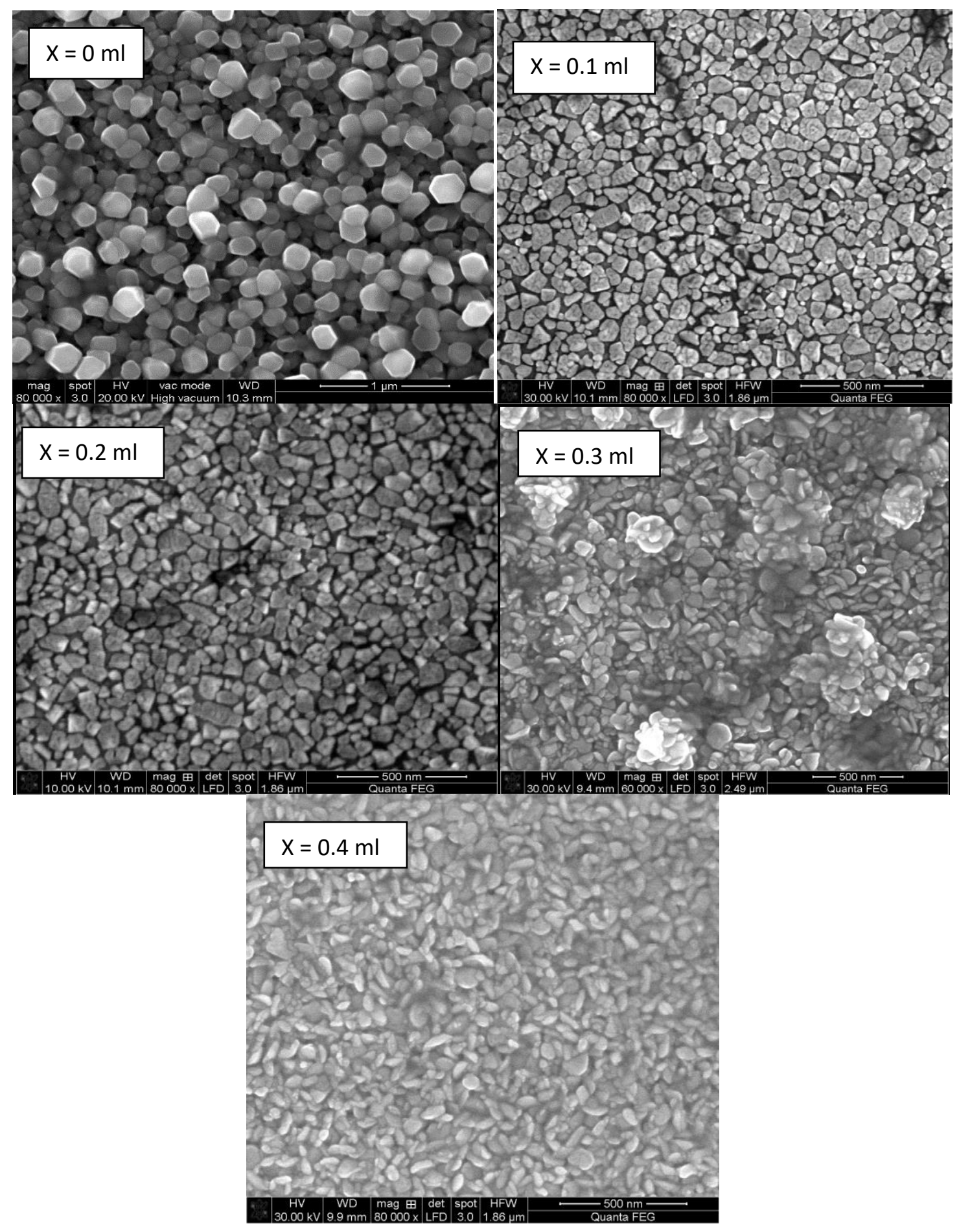

Fig. 8 SEM micrographs of pure and $\mathbf{N}$ doped thin films for different doping concentrations $(x)$ 
It is clearly seen uniform surface morphology in all the prepared samples. The surface of the films looks to be smooth and without any crack and holes. In the pure sample, the grains are in sperical shape. In doped sample, the shape of the grains are non-spherical, it changes with doping concentrations. On increasing the doping concentrations, the shape of the grains changes through polygoanal, flower and ricelike structure. Estimated grain size decreases with increasing doping concentrations. Grain size decreases from $90 \mathrm{~nm}$ to $42 \mathrm{~nm}$, when the $\mathrm{N}$ doping concentartion increases. Grain size decreasing with increasing film thickness and obtained grains sizes well match with grain size obtained from XRD spectra. Shape modifications in grains give significant property modifications which find applications in optoelectronic industry.

\subsubsection{Atomic Force Microscopy}

Fig .9 Shows the Atomic force microscopy (AFM) image of the $\mathrm{ZnO}$ thin for undoped and $\mathrm{N}$ doped $\mathrm{ZnO}$ films.
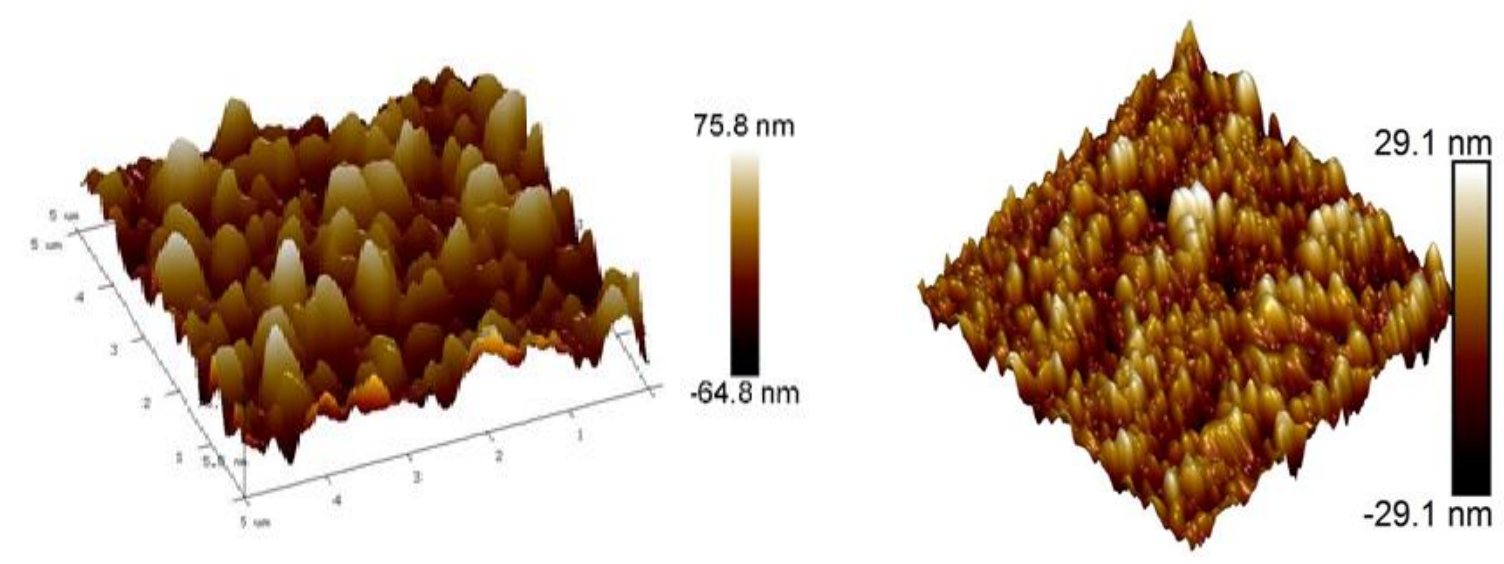

Fig. 9 AFM image of pure and $\mathrm{N}$ doped $\mathrm{ZnO}$ films for different concentrations (x)

From Fig. 9 it is clealy noted that the obtained flms conisit of perpendicular grains with narrow grain size distribution. Smooth and uniform films are obtained with average roughness of $22 \mathrm{~nm}$ (undoped) and $23.7 \mathrm{~nm}$ ( $\mathrm{N}$ doped $\mathrm{ZnO}$ films). Surface roughness is high in $\mathrm{N}$ doped $\mathrm{ZnO}$ 
thin films. The values of the grain size calculated using AFM were found to be $75.8 \mathrm{~nm}$ and $29.1 \mathrm{~nm}$. The crystallite size seems to be decrease in $\mathrm{N}$ doped $\mathrm{ZnO}$ thin film. Obtained grain size values are in agreement with the crystallite size values obtained through XRD studies and SEM analysis.

\subsubsection{Energy Dispersive X-ray Spectroscopy (EDAX)}

Fig. 10 shows the EDAX spectra of prepared Zno thin films. The atomic concentrations of $\mathrm{N}$ doped Zno thin films are shown in fig.

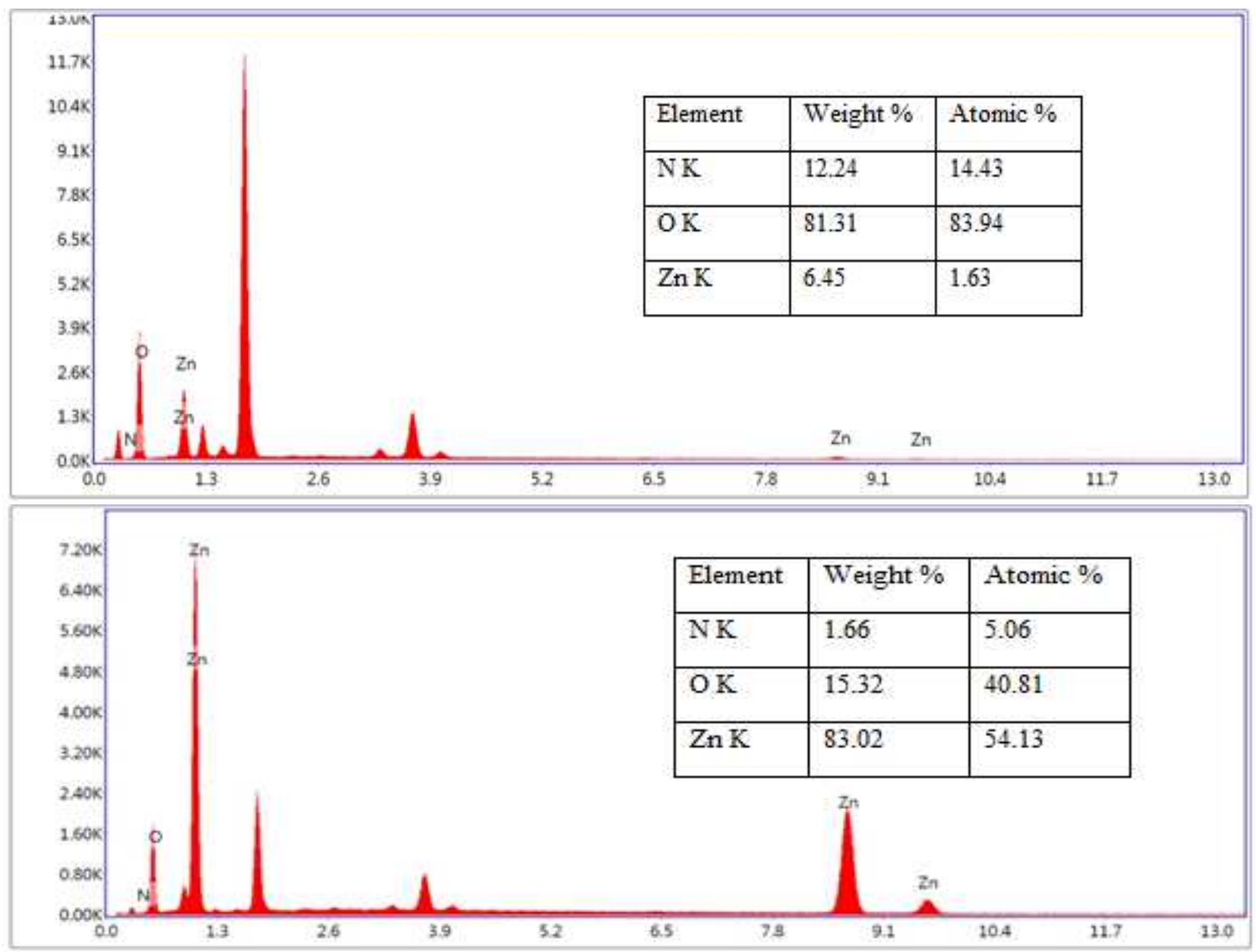



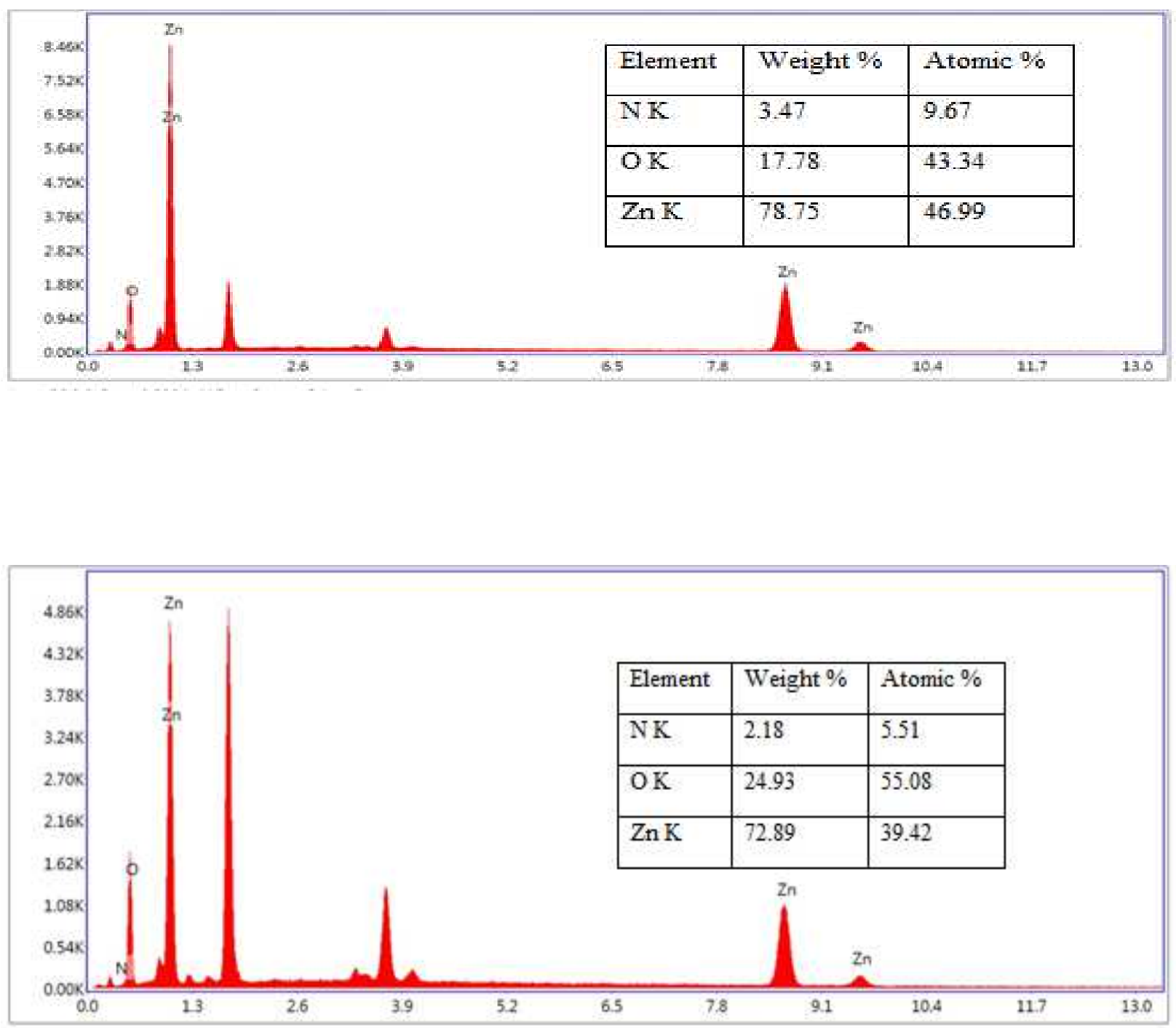

Fig. 10 EDAX Spectra of $\mathrm{N}$ doped ZnO thin films for different doping concentrations (x)

EDAX reveals the presence of required elemental composition of Zinc (Zn) Oxygen (O) and Nitrogen $(\mathrm{N})$ in the samples. The obtained results shows that the $\mathrm{N}$ atoms were heavily incorporated in the $\mathrm{ZnO}: \mathrm{N}$ films. The peak at $0.39 \mathrm{keV}$ represents the nitrogen atom. No other peaks were spotted for the undoped $\mathrm{ZnO}$ samples. The prominent peaks at $0.39 \mathrm{keV}$, $0.59 \mathrm{keV}, 1.03 \mathrm{keV}, 8.44 \mathrm{keV}$ and $9.33 \mathrm{keV}$ were strongly observed for all the $\mathrm{N}$ doped samples. From these, peaks located at $0.59 \mathrm{keV}$ and $1.03 \mathrm{keV}$ represents the $\mathrm{K}$ shell of oxygen and $\mathrm{L}$ shell 
of zinc. In detail,the L-shell emission at $1.03 \mathrm{keV}$, as observed here can be measured as the convolution of $\mathrm{Zn} 2 \mathrm{p}_{3 / 2}$ and $\mathrm{Zn} 2 \mathrm{p}_{1 / 2}$ photoelectron energies, which have been reported at $1.02 \mathrm{keV}$ and $1.04 \mathrm{keV}$ respectively. The $\mathrm{X}$-ray energies at $8.44 \mathrm{keV}$ and $9.33 \mathrm{keV}$ are added emissions from $\mathrm{Zn}$ core levels . Over all the existence of these basic $\mathrm{Zn}$ and $\mathrm{O}$ emissions endorse the existence of $\mathrm{Zn}$ and $\mathrm{O}$ atoms in prepared nano particles. As evident through the presence of N1 score level emission around $0.39 \mathrm{keV}$.

\section{Conclusion}

Pure and $\mathrm{N}$ doped $\mathrm{ZnO}$ thin films were synthesized successfully by using spray pyrolysis method. Obtained results shows that the structural and surface morphology of the $\mathrm{ZnO}: \mathrm{N}$ films depend strongly doping concentration. On doping, initially the crystallinity of the prepared films was poor. The average value of crystallite size was decreased from 40 to $24 \mathrm{~nm}$ when $\mathrm{N}$ concentration is increased, due to the suppression of nucleation and successive growth. Higher $\mathrm{N}$-doping significantly improved the crystallite size by creation of distortion centers and $\mathrm{Zn} / \mathrm{N}$ interstitials. Presence of chemical bonding between $\mathrm{Zn}-\mathrm{O}$ was confirmed through FTIR and FT-Raman spectra. Observed shift in these bands confirmed the substitution of $\mathrm{N}$ into $\mathrm{ZnO}$ lattice. From SEM studies, high resolution images revealed smooth and crack free surfaces. Changes in the shape and size of the surface microstructures revealed dependency to doping concentrations. Rouhghness of films increases for $\mathrm{N}$ doped $\mathrm{ZnO}$ thin films.EDAX analysis confirms the presence of $\mathrm{Zn}, \mathrm{O}$ and $\mathrm{N}$ element.

\section{References}

[1] Makwena, J \& Moloto, NM, 2019, 'Bis (2-hydroxy-1-naphthaldehydato) zinc (II) as a precursor for the preparation of $\mathrm{ZnO}$ thin films through aerosol-assisted chemical vapor deposition', Thin Sold Films, vol. 670, pp.99-104. 
[2] Tomoaki, T, , Yoshinori, O \& Masakazu, Y, 2019, 'Effects of $\mathrm{NH}_{3}$ flow on structural and optical properties of $\mathrm{ZnO}$ films grown by atmospheric-pressure chemical vapor deposition', Thin Solid Fillms, vol. 675, pp.50-58.

[3] Henni, A Harfouche, N Karar, A, Zerrouki, D, Perrin, FX \& Rosei, F 2019, ‘Synthesis of graphene- $\mathrm{ZnO}$ nanocomposites by a one-step electrochemical deposition for efficient photocatalytic degradation of organic pollutant', Solid State Sciences, vol. 98, pp. 06039.

[4] Shashikant, R \& Kumar, SR 2017, 'Effect of Annealing on Nano crystalline ZnO Thin Film Developed by Electro deposition Method', Materials Today: Proceedings, vol.4, pp. 3754-3759.

[5] Vahid, M, Kosala, Y, Shiqiang, W, Khanala MP, Upretya, S, Muhammad, SS, Burcu, O, Ayayi, CA, Michael, CH, Mobbassar, HS \& Minseo, P 2019, 'On the anomaly in the electrical characteristics of thin film transistors with multi-layered sol-gel processed ZnO', Thin Solid Films, vol. 672, pp. 152-156.

[6] Muneer, M, Ba-Abba, Kadhum, AAH, Mohamad, AB, Takriff, MS \& Kamaruzzaman, S 2013, 'The effect of process parameters on the size of $\mathrm{ZnO}$ nanoparticles synthesized via the sol-gel technique', Journal of Alloy and Compounds, vol. 550, pp. 63-70.

[7] Tuzemen, ES, Kamuran, K, Sezai, E, Deniz, KT, Ismail, A \& Ramazan, E 2014, 'Structural and electrical properties of nitrogen-doped $\mathrm{ZnO}$ thin films, Applied Surfface Science,

[8] Vasile, T, Ioana-Laura, V, Dana, S, Helene, M \& Lucel, S, 2016 'High visible light photocatalytic activity of nitrogen-doped $\mathrm{ZnO}$ thin films deposited by HiPIMS' Surface \& Coatings Technology

[9] Soumen, D \& Giri,PK 2012, 'Stable p-type conductivity and enhanced photoconductivity from nitrogen doped annealed $\mathrm{ZnO}$ thin film', Thin Solid Films, vol.520, pp.5000-5006.

[10] Parmod K, Hitendra KM, Anima G, Thangavel, R \& Asokan, K 'An insight to origin of ferromagnetism in $\mathrm{ZnO}$ and $\mathrm{N}$ implanted $\mathrm{ZnO}$ thin films:Experimental and $\mathrm{DFT}$ approach', Journal of Alloys and Compounds, vol.

[11] Mbamara, US, Olofinjana, B , Ajayi, OO, Lorenzo-Martin, C, Obiajunwa, EI\& Ajayi, EOB 2016, 'Friction and wear behavior of nitrogen-doped $\mathrm{ZnO}$ thin films deposited via 
MOCVD under dry contact', Engineering Science and Technology, an International Journal, vol.19, pp. 956-963.

[12] Xiaonan, L, Sally, EA, Limpijumnong S, Brian, MK, Craig, LP,Teresa, MB, Helio, RM, Joseph, ML, Zhang, SB, Su-Huai, W \& Timothy, JC 2006, 'Impurity effects in ZnO and nitrogen-doped $\mathrm{ZnO}$ thin films fabricated by MOCVD', Journal of Crystal Growth, vol. 287, pp. 94-100.

[13] Shinho, C 2010, 'Properties of nitrogen and aluminium-codoped $\mathrm{ZnO}$ thin films grown with different nitrogen flow ratios for solar cell applications', Current Applied Physics, vol.10, pp. S443-S446.

[14] Jinhuan, J, Yongfeng, L, Bin, Y, Zhanhui, D, Ruijian, L, Rui, D, Ligong, Z, Haifeng, Z \& Lei, LJ, 'Role of nitrogen-related complex in stabilizing ferromagnetic ordering in a rareearth and nitrogen codoped $\mathrm{ZnO}^{\prime}$, Ceramics International,

[15] Ching-Chung, W, Chao-Ming, F \& Yu-Min, H 2013, 'Intrinsic defects responsible for the anomalous Raman peaks and the room-temperature ferromagnetism in nitrogen-doped ZnO thin films', Surface \& Coatings Technology, vol. 231, pp. 307-310.

[16] Ramanjaneyulu Mannam Senthil Kumar Eswaran Nandita DasGupta M.S. Ramachandra Rao, Zn-vacancy induced violet emission in p-type phosphorus and nitrogen codoped $\mathrm{ZnO}$ thin films grown by pulsed laser deposition, Applied Surface Science

[17] Karamat, S, Rawat, RS, Tan, TL, Lee, P, Springham,SV, Ghareshabani, E, Chen, R \& Sun, HD 2011, 'Nitrogen doping in pulsed laser deposited $\mathrm{ZnO}$ thin films using dense plasma Focus', Applied Surface Science, vol. 257, pp.1979-1985.

[18] Liang-Chiun, C, Jun-Wei, C, Han-Chen, P \& Ching-Hwa, H 2013, 'Characterization of nitrogen doped p-type $\mathrm{ZnO}$ thin films prepared by reactive ion beam sputter deposition', Surface \& Coatings Technology, vol. 231, pp. 492-495.

[19] Khalid, M \& Arshi, K 'Single-step electrospray deposited nitrogen-doped ZnO nanosheets yield hysteresis- free perovskite solar cells, Materials Letters

[20] Rishi, V, Sarla, S, Parul, G, Arun, KP, Dhara, SK, Tyagi, AK, Sachdev, K \& Sharma, SK 2013 'Nitrogen dioxide induced conductivity switching in $\mathrm{ZnO}$ thin film', Journal of Alloys and Compounds, vol. 571, pp. 6-11.

[21] Yacine, A, Boubaker, B, Benramache, S \& Brahim G, 'Effect of deposition rate on the structural, optical and electrical properties of Zinc oxide $(\mathrm{ZnO})$ thin films prepared by 
spray pyrolysis technique', Optik - International Journal for Light and Electron Optics, vol. 126(20), pp.2481-2484.

[22] Ameur, SB, Barhoumi, A, Mimouni, R, Amlouk, M \& Guermazi, H 2015, 'Lowtemperature growth and physical investigations of undoped and (In, Co) doped $\mathrm{ZnO}$ thin films sprayed on PEI flexible substrate', Superlattices and Microstructures, vol. 84, pp. 99-112.

[23] Enigochitra, AS, Perumal, P Sanjeeviraja,C, Deivamani \& Boomashri, M 2015, 'Influence of substrate temperature on structural and optical properties of $\mathrm{ZnO}$ thin films prepared by cost-effective chemical spray pyrolysis technique', Superlattices and Microstructures, vol. 90, pp. 313-320.

[24] Dhanakodi, K, Thirunavukkarasu, P, Mariappan, R \& Rajamanickam, AT 2016, 'Effect of substrate temperature on the nebulizer sprayed zinc oxide thin films', Optik, vol. 127, pp. $2516-2520$

[25] Nunes, P, Fortunato, E, Lopes, A, \& Martins, R 2001, 'Influence of the deposition conditions on the gas sensitivity of zinc oxide thin films deposited by spray pyrolysis', International Journal of Inorganic Materials, vol. 3, pp.1129-1131.

[26] Ravichandran, K, Santhosam, AJ \& Sridharan, M 2020, 'Effect of tungsten doping on the ammonia vapour sensing ability of $\mathrm{ZnO}$ thin films prepared by a cost effective simplified spray technique', Surfaces and Interfaces, vol. 18, pp. 100412.

[27] Trilok, KP, Vinod, K, Swart, HC \& Purohit, LP "Effect of doping concentration on the conductivity and optical properties of p-type $\mathrm{ZnO}$ thin films” Physica B

[28] Kumari, R, Anshuman, S, Goswami, N 2015, 'Effect of nitrogen doping on structural and optical properties of ZnO nanoparticles', Progress in Nature Science, vol. 25, pp. 300309.

[29] Trilok, KP, Vinod, K, JaiPrakash, Purohi LP, Swart HC \& Kroon, RE 2016, 'Fabrication and Characterization of Nitrogen Doped P-ZnO on n-Si Heterojunctions', Sensors and Actuators, vol.247, pp. 475-481. 
[30] Ashokkumar, M \& Muthukumaran, S 2014, 'Microstructure, optical and FTIR studies of $\mathrm{Ni}, \mathrm{Cu}$ co-doped $\mathrm{ZnO}$ nanoparticles by co-precipitation method', Optical Materials, vol. 37, pp. 671-678.

[31] Keyue, W, Qingqing, F, Weina, W, Thomas, TA \& Jingbiao, C 'On the origin of an additional Raman mode at $275 \mathrm{~cm}^{-1}$ in N-doped $\mathrm{ZnO}$ thin films', Journal of Applied Physics, vol. 111(6) pp. 063530.

[32] Xiaming, Z, Huizhen, W, Zijian, Y, Jinfang, K \& Wenzhong, S, 2015, 'Multiphonon resonant Raman scattering in N-doped ZnO', Journal of Raman spectroscopy, vol. 40(12), pp. 2155-2161.

[33] Belkhalfa, H, Ayed, H, Hafdallah, A, .Aida, MS \& Ighi, RT 'Characterization and studying of Zno thin films deposited by spray pyrolysis : effect of annealing temperature' 